\title{
EFFECT OF DIFFERENT FEEDING AND FEED DEPRIVATION CYCLES ON GROWTH PERFORMANCE OF NILE TILAPIA (Oreochromis niloticus)
}

\author{
(Received: 29.6.2015) \\ By \\ A. Suloma, M.A. Elnady, M.A. Salem and M.M. Abd El-Hamid * \\ Department of Animal Production, Faculty of Agriculture, Cairo University \\ * General Authority for Fish Resources Development, Ministry of Agriculture, Cairo, Egypt.
}

\begin{abstract}
Nile tilapia juveniles ( $24.8 \mathrm{~g} / \mathrm{fish}$ ) were subjected to four feeding regimes (32 fish per tank) that included three feed deprivation and refeeding cycles for a duration of 84 days. Each feeding cycle constituted one treatment. The one day deprivation cycle included feed deprivation for one day followed by three days re-feeding period. The two-day deprivation cycle included food deprivation for two days followed by six-day re-feeding period. The three days deprivation cycle included feed deprivation for three days followed by nine-day of re-feeding period. All food deprivation cycles were repeated all over the experimental period. The control treatment was fed to satiation every day without any period of food deprivation. Nile tilapia was fed with commercial extruded diet $(32 \%$ crude protein). Starting with initial weights of 24.4-25.2 g/fish at the start of the experiment. Nile tilapia grew to $55.0-71.3 \mathrm{~g} / \mathrm{fish}$ at harvest time, with significant differences in growth patterns among treatments $(\mathrm{P}<0.05)$. Fish within food deprivation treatment did not differ significantly in terms of final body weight which ranged from 55.0 to $63.02 \mathrm{~g} /$ fish $(\mathrm{P}<0.05)$. However, the control treatment had a higher body weight by 13 to $29 \%$ compared with all feed deprivation treatments. This was expected since the control fish group consumed more food intake $0.86 \mathrm{~g}$ diet/fish/day compared to all feed deprivation groups that consumed 0.54 to $0.7 \mathrm{~g}$ diet /fish/day during the course of the experiment $(\mathrm{p}<0.05)$. When comparing weight gain and total feed intake of the 3 days fasting cycle $(42.08 \mathrm{~g} / \mathrm{fish}$ and $59.0 \mathrm{~g}$ diet/fish, respectively) with those of the control treatment $(46.6 \mathrm{~g} /$ fish and $72.7 \mathrm{~g}$ diet/fish, respectively), it can be concluded that despite fish were exposed to three-day fasting cycle, weight gain was lower by $19 \%$, while total feed intake was lower by $18 \%$ compared to the continuous feeding control treatment. During fasting period (21 days in each of the three cycles) Fish consumed energy for routine metabolism needed for survival. Energy required for fish survival during the fasting period (21 days) was obtained from dietary energy consumed during re-feeding periods. This should have negatively affected feed conversion ratio if this energy were to be deduced from the feed intake fed during the experiment. All fasting treatments had similar feed conversion ratio compared to the continuous feeding (control) group $(\mathrm{P}<0.05)$ which indicate that FCR in the food deprivation groups was compensated during re-feeding by a decrease in metabolic costs or an improvement in feed utilization.
\end{abstract}

Key words: Feed Deprivation, Compensatory growth, Feeding cycles ,Nile tilapia.

\section{INTRODUCTION}

Tilapias are omnivorous fish meaning that they feed on a low trophic level. Tilapia exhibited best growth performance when they are fed a diet containing a proper balance of protein, carbohydrates, lipids, vitamins, minerals and fiber (Suresh, 2003, Suloma and Ogata, 2006, Suloma, et al. 2008; Suloma and Ogata, 2012). The practical daily feeding of fish involves two systems, 1) feed the fish to satiation 2) feed a restricted ration (Suresh,
2003). Fish feed to satiation normally exhibit the best growth and poor feed conversion ratio. Also, it is difficult to determine satiation levels in fish because food consumption occurs in the water medium (Tacon, 1987). This may lead to overfeeding, which is wasteful and deleterious to water quality. Alternative system is to explore cyclic feed reduction and re-feeding (RR), which is a process that has improved growth rates and feed conversion efficiency in fish recovering from feed deprivation (Boujard et al., 2000 and 
Silverstein, 2006). Once metabolic function returns to normal levels, compensatory growth (CG) or "catch-up growth" which is the superaccelerated growth occurs in a period following the period of sub-optimal conditions, such as following feed deprivation or low temperature. Many aquatic species have also been shown to exhibit CG (Ali et al., 2003). Growth rate in fish is often limited by food availability (Weatherley and Gill, 1987 and Wootton, 1998). When food supply is increased following a period of starvation or restricted feeding, fishes and other animals may display a growth spurt, often referred to as catch-up or compensatory growth (Wilson and Osbourn, 1960, Weatherley and Gill, 1981, Dobson and Holmes, 1984, Pitts, 1986 and Jobling et al., 1994). Most studies of compensatory growth in fishes have used a single phase of food deprivation and satiation feeding to elicit compensatory response (Dobson and Homes, 1984, Miglavs and Jobling, 1989 and Paul et al., 1995). A few studies have employed cycles of food deprivation and satiation re-feeding to investigate the dynamics of compensatory growth including the time fish spent in a compensatory growth phase (Kindschi, 1988, Quinton and Blake, 1990 and Jobling et al., 1993). In these studies, all feed deprivation and satiation re-feeding cycles were tested with different ratios. Therefore, the objective of present study was to test the effect of the duration of food deprivation under fixed ratio of fasting and refeeding cycles on growth performance and feed efficiency of Nile tilapia.

\section{MATERIALS AND METHODS}

The current study was carried out between 7 May and 28 July 2014 (12 weeks) at the Fish Nutrition Lab, Animal Production Department, Faculty of Agriculture, Cairo University, Egypt.

\subsection{Experimental fish}

Nile tilapia juveniles were purchased from a commercial tilapia hatchery, village No.12, ElHamoul province, Kafr El-Sheikh Governorate, Egypt. Fish were healthy and free of parasites. The Fish were individually weighed to the nearest $0.01 \mathrm{~g}$ using digital balance. The average body weight was $24.8 \pm 1.1 \mathrm{~g}$. The experimental fish were randomly distributed among 12 tanks (32 fish per tank) and kept for adaptation period of 10 days before the start of the experiment.

Nile tilapia were distributed into 12 fiber glass tanks (700 litre each) in outdoor area. Photoperiod was natural. Nile tilapia was fed twice a day with commercial extruded diet $(32 \%$
CP). The fish were fed to apparent satiation. Each tank was equipped with individual aeration system and running water. Every day feces at the bottom of the tanks were siphoned and complete renewal of tank was done every four days.

\subsubsection{Diet and feeding}

Commercial Nile tilapia diet was purchased from "Zoo Control factory" and used in the current experiment. The nutrient composition and pellet size for the diet are shown in Table (1).

Table (1): Nutrient composition of the commercial Nile tilapia diet used in the study

\begin{tabular}{|l|l|}
\hline Parameter & Zoo control diet \\
\hline Type & Extruded pellets \\
Size of pellet & $2.0 \mathrm{~mm}$. \\
\hline \multicolumn{2}{|l|}{ Proximate composition $\mathbf{( \% )}$} \\
\hline Crude protein & $32 \%$ \\
Crude lipid & $6.74 \%$ \\
Crude ash & $10 \%$ \\
Moisture & $6 \%$ \\
NFE & $45.26 \%$ \\
gross energy $(\mathrm{Kcal} / \mathrm{g})$ & 5.9 \\
\hline
\end{tabular}

\subsubsection{Experimental design}

After 10 days of adaptation before the start of the experiment, the fish were randomly assigned to four feeding groups with two replicates for each treatment. The ratio of the duration of refeeding and feeding deprivation was 3:1 in all treatments, except for the control which had continuous feeding. There were four feeding regimes in the experiment as follows

\subsubsection{The control treatment}

Fish in the control treatment were fed to satiation every day, without any period of food deprivation during the experiment.

\subsubsection{One day feed deprivation treatment}

The one-day feed deprivation treatment included one day of feed deprivation followed by three days of re-feeding period which constituted one cycle that was repeated all over the experiment at period.

\subsubsection{Two day feed deprivation treatment}

The two-day feed deprivation treatment included two days of feed deprivation followed by six days of re-feeding period which constituted one cycle that was repeated all over the experiment at period.

\subsubsection{Three day feed deprivation treatment}

The three-day feed deprivation treatment included three days feed deprivation followed by 
nine days of re-feeding period which constituted one cycle repeated all over the experiment.

Fish were fed twice a day and daily feed consumption was recorded. A total of 63 feeding days and 21 fasting days were included in all treatmensts during the experiment while the control treatment was fed every day until the end of the expriment as shown in Table (2).

Table (2):Cycles of fasting and re-feeding in the experimental groups

\begin{tabular}{|l|c|c|c|}
\hline \multicolumn{1}{|c|}{ Groups } & $\begin{array}{c}\text { Fasting } \\
\text { (days) }\end{array}$ & $\begin{array}{c}\text { Feeding } \\
\text { (days) }\end{array}$ & $\begin{array}{c}\text { Fasting- } \\
\text { feeding } \\
\text { cycles }\end{array}$ \\
\hline Control & 0 & 84 & 0 \\
\hline $\begin{array}{l}\text { Three days feed } \\
\text { deprivation }\end{array}$ & 21 & 63 & 7 \\
\hline $\begin{array}{l}\text { Two days feed } \\
\text { deprivation fon }\end{array}$ & 21 & 63 & 10.5 \\
\hline $\begin{array}{l}\text { One day feed } \\
\text { deprivation }\end{array}$ & 21 & 63 & 21 \\
\hline
\end{tabular}

Food consumption was measured every day in order to calculate the feeding rate and feed conversion ratio (FCR). All fish were weighed individually every 18 days following $24 \mathrm{~h}$ of starvation. Fish were not fed on the day of weighing. When fasting period was finished, refeeding was started during each cycle. At the end of the trial, five fish were randomly taken from each tank to determine gut length and chemical composition.

\subsection{Growth and feed performance}

Growth performance of the cultured fish was measured in terms of final individual fish weight (g), daily weight gain (g/fish/day), weight gain (g/fish), specific growth rate (SGR-\%/day), feed conversion ratio (FCR) and protein efficiency ratio (PER).

\subsubsection{Relative gut length parameter}

In order to see the effects of feeding regimes on the gut length of the experiment at the end, three fish from each tank were collected and dissected, and their total length was measured as relative gut length.

\subsubsection{Chemical composition of diets and fish}

Experimental diets and fish samples were analyzed for chemical composition (Williams, 1984). Fish were frozen soon afterward at temperature of $-20^{\circ} \mathrm{C}$. To obtain a homogenous material, fish were dried at $60^{\circ} \mathrm{C}$ overnight to determine dry matter content (DM). The crude protein content $(\mathrm{CP})$ was determined by micro kjeledahel method ( $\mathrm{n} \times$ 6.26). Ether extract (EE) was determined in soxhelt apparatus using petroleum ether $\left(60-80{ }^{\circ} \mathrm{C}\right)$. Ash content was determined in the muffle furnace at $550{ }^{\circ} \mathrm{C}$ for 3 hours. The gross energy (GE) content (Kcal GE $\mathrm{kg}^{-1}$ ) in feed and fish was calculated using factors $5.65,4.2,9.45 \mathrm{Kcal} / \mathrm{g}$ for protein, carbohydrate and lipid, respectively.

\subsubsection{Water quality and environmental parameters}

Water temperature and $\mathrm{pH}$ value were measured by thermometer and $\mathrm{pH}$ meter device, respectively. Dissolved oxygen (DO) was measured by DO meter and maintained above $5.0 \mathrm{mg} \mathrm{l}-1$ during the feeding trial by increasing flow rate. Dissolved inorganic nutrients (NH4, $\mathrm{NO} 3$, and NO2) were determined by using a spectrophotometer (model DR/2010.).Samples were analyzed at The Nutrition Lab., General Authority for Fish Resources Development (GAFRD), Cairo, Egypt.

\subsection{Statistical analysis}

Growth and feed performance of cultured fish as well as water quality parameters in culture tanks were statistically analyzed by one way ANOVA using SPSS (version 11.0). Significant differences among the means of different treatments were determined by Duncan's multiple range test $(\mathrm{P}=0.05)$.

\section{RESULTS AND DISCUSSION}

\subsection{Effect of fasting and re-feeding on growth} performance.

Growth performance of Nile tilapia juveniles are shown in Table (3). Starting with initial weights of 24.4-25.2 g/fish at the start of the experiment, Nile tilapia grew to $55.0-71.3 \mathrm{~g}$ /fish at harvest time, with significant differences between treatments $(\mathrm{P}<0.05)$. The highest average final weight of Nile tilapia was observed in the control treatment (71.3 g/fish) with continuous feeding compared to those under 1 to 3 days of feed deprivation $(55.0-63.02 \mathrm{~g} /$ fish $)$ which had significantly lower FBW.

Final body weights under food deprivation did not differ significantly and ranged from 55.0 to $63.02 \mathrm{~g} /$ fish $(\mathrm{p}<0.05)$. However, the control treatment had a higher BW by 13 to $29 \%$ compared with all food deprivation treatments. This was expected since the control fish group consumed more FI (0.86 g diet/fish/day) compared to all food deprivation groups that consumed 0.54 to $0.70 \mathrm{~g}$ diet /fish/day during the course of the experiment $(\mathrm{p}<0.05)$ as shown in Table (4). 
Table (3) : Growth performance of Nile tilapia reared under different fasting and re-feeding cycles

\begin{tabular}{|c|l|l|l|l|}
\hline Parameters & \multicolumn{1}{|c|}{ Control } & 3 day fasting & 2 day fasting & \multicolumn{1}{c|}{ 1 day fasting } \\
\hline Survival rate $\%$ & $97.91 \pm 2.08^{\mathrm{a}^{*}}$ & $88.54 \pm 2.75^{\mathrm{a}}$ & $97.91 \pm 2.08^{\mathrm{a}}$ & $94.79 \pm 5.20^{\mathrm{a}}$ \\
\hline Initial weight $(\mathbf{g})$ & $24.78^{\mathrm{a}}$ & $25.23^{\mathrm{a}}$ & $25^{\mathrm{a}}$ & $24.43^{\mathrm{a}}$ \\
\hline FBW(g) & $71.35 \pm 3.67^{\mathrm{a}}$ & $63.02 \pm 1.1^{\mathrm{ab}}$ & $55.09 \pm 3.67^{\mathrm{b}}$ & $61.27 \pm 4.11^{\mathrm{ab}}$ \\
\hline Gain(g) & $46.63 \pm 9.32^{\mathrm{a}}$ & $42.08 \pm 0.59^{\mathrm{ab}}$ & $30.09 \pm 3.45^{\mathrm{b}}$ & $36.85 \pm 4.23^{\mathrm{ab}}$ \\
\hline SGR & $1.26 \pm 0.9^{\mathrm{a}}$ & $1.07 \pm 0.01^{\mathrm{ab}}$ & $0.93 \pm 0.07^{\mathrm{b}}$ & $1.07 \pm 0.08^{\mathrm{ab}}$ \\
\hline
\end{tabular}

*Means in the same row with different superscripts are significantly different $(\mathbf{P}<0.05)$

Table (4): Feed performance of Nile tilapia reared under different fasting and re-feeding cycles

\begin{tabular}{|l|l|l|l|l|}
\hline Parameters & \multicolumn{1}{|c|}{ Control } & 3 day fasting & 2 day fasting & 1 day fasting \\
\hline Total Fintake & $72.72 \pm 6.3^{\mathrm{a}^{*}}$ & $59.09 \pm 5.41^{\mathrm{a}}$ & $45.43 \pm 6.05^{\mathrm{b}}$ & $54.33 \pm 7.7^{\mathrm{b}}$ \\
\hline $\begin{array}{l}\text { Feed intake }^{1} \\
\text { (g/fish/day) }\end{array}$ & $0.86 \pm 0.07 \mathrm{a}$ & $0.70 \pm 0.064^{\mathrm{ab}}$ & $0.54 \pm 0.073^{\mathrm{b}}$ & $0.64 \pm 0.091^{\mathrm{ab}}$ \\
\hline $\begin{array}{l}\text { Feed intake }^{2} \\
\text { (g/fish/day) }\end{array}$ & $0.86 \pm 0.075^{\mathrm{a}}$ & $0.93 \pm 0.023^{\mathrm{ab}}$ & $0.72 \pm 0.09^{\mathrm{b}}$ & $0.86 \pm 0.12^{\mathrm{ab}}$ \\
\hline FCR & $1.56 \pm 0.02^{\mathrm{a}}$ & $1.54 \pm 0.14^{\mathrm{a}}$ & $1.50 \pm 0.04^{\mathrm{a}}$ & $1.47 \pm 0.06^{\mathrm{a}}$ \\
\hline PER & $2.00 \pm 0.03^{\mathrm{a}}$ & $1.99 \pm 0.16^{\mathrm{a}}$ & $2.08 \pm 0.09^{\mathrm{a}}$ & $2.13 \pm 0.5^{\mathrm{a}}$ \\
\hline RGL & $4.80 \pm 0.13 \mathrm{~b}$ & $5.75 \pm 0.11 \mathrm{a}$ & $5.80 \pm 0.15 \mathrm{a}$ & $4.60 \pm 0.09 \mathrm{~b}$ \\
\hline
\end{tabular}

*Means in the same rw with different superscripts are significantly different $(P<0.05)$

The results of the present study indicated that FBW of fish under feed deprivation was less by 13 to $29 \%$ compared to the control group. Nile tilapia experiencing food deprivation cycles consisting of 21 days of food deprivation and 63 days of satiation feeding did not achieve the same FBW as fish continuously fed during the current experiment. WG and specific growth rates were significantly lower in all feed deprivation treatment (30.0-37.4 g/fish and 0.93$1.09 \%$ per day, respectively) compared to those of the control treatments (46.6 g/fish and $1.26 \%$ per day a respectively). This was due to negative effect of feed deprivation on total FI during the experiment (i.e. number of fasting days $=21$ days for food deprivation treatments while the duration of the experiment was 84 days).

Total FI during the whole duration of the experiment (84 days) were significantly lower in all food deprivation groups (45.4-59.09 $\mathrm{g}$ diet/fish) compared to that of the control group (72.7g diet / fish) by $18-37 \%$.The three day deprivation treatment was good in terms of total FI (59.09 g diet/fish), weight gain (42.08 g / fish) despite being exposed to three days food deprivation cycles.
The overall mean FBW and WG of all feed deprivation groups $(59.7 \mathrm{~g} / \mathrm{fish}$ and $34.8 \mathrm{~g} / \mathrm{fish}$, respectively) were lower by $16 \%$ and $25 \%$ respectively, compared to those of the control treatment. When comparing WG and total FI of the 3 days fasting cycle $(42.08 \mathrm{~g} /$ fish and $59.0 \mathrm{~g}$ diet/fish, respectively) with those of the control treatment (46.6 $\mathrm{g} / \mathrm{fish}$ and $72.7 \mathrm{~g}$ diet/fish, respectively), it can be concluded that despite fish were exposed to three days fasting cycle, WG was lower by $19 \%$, while total FI was lower by $18 \%$ compared to the continuous feeding control treatment. Fish did not show full compensation by the end of the experiment in all feed deprivation treatments.

The results of the current experiment are in agreement with the results of Xiao et al. (2013), while are in disagreement with the results of Gaylord and Galtin (2001) and Nebo et al.(2013). Gaylord and Gatlin (2001) reported that, when fish groups were exposed to three cycles, each consisting of 3 days of deprivation and 11 days of satiation feeding, the deprived fish showed full compensation by the end of the 6 weeks. Xiao et al. (2013) reported that shortterm deprivation ( 1 and 2 days per week) 
resulted in complete compensation in black sea bream, while fish experiencing longer term starvation (3 and 4 days per week) could not achieve the same final body weight as fish continuously fed.

Nebo et al. (2013) reported that short periods of fasting followed by refeeding ( 5 days of fasting and 37 of refeeding) recovered the body mass, which was similar to that observed in continuous feeding (42 days of feeding). However, when fish was fasted for 10 days and followed by 32 days of refeeding, the body mass was lower than other treatments.

In contrast, Urbinati et al. (2014) found that the FBW of matrinxã (Brycon amazonicus) did not differ among feeding strategies, at the end of the experiment. But in a comparable experiment in which catfish experienced 3,5 or 7 days of feed deprivation in each 14-day cycle, even the fish experiencing the lowest level of deprivation failed to show compensation (Gaylord and Gatlin 2001).

As shown in Table (4), total FI and FI upon re-feeding (re-alimentation) did not increase in all feed deprivation treatments (45.4-59.0 g diet/fish and 0.72-0.93 g diet / fish/ day, respectively) compared to those of the control group (72.7 $\mathrm{g}$ diet/fish and $0.86 \mathrm{~g} \mathrm{diet/} \mathrm{fish/} \mathrm{day,}$ respectively). Fish did not show hyperphagia or increased feed conversion efficiency upon realimentation in all fasting-refeeding cycles during the current experiment.

Compensatory growth could be divided into different categories according to the degree at which it is occurring (Ali et al., 2003). The exact mechanisms of compensatory growth are still to be understood (Urbinati et al., 2014). However, it is suggested that during re-feeding, GR is compensated by either a decrease in metabolic costs, an increase in FI or an improvement in feed utilization. Indeed, lower basal metabolism (O'Connor et al., 2000), hyperphagia (Gaylord and Gatlin, 2001, Gurney et al., 2003, Hayward et al., 1997, Jobling, 2010, Känkänen and Pirhonen, 2009, Wang et al., 2000, Xiao et al., 2013) and increased feed conversion efficiency (Jobling, 2010, Skalski et al., 2005, Xiao et al., 2013) have been observed in several fish species following periods of starvation or intermittent feeding.

The evrrent results are in agreement with Ali and Wootton (2001) who reported that the hyperphagia was not maintained on the second day of re-feeding. In other studies in which the re-feeding phase of the deprivation-feed cycle was more than 2 days, the hyperphagia persisted for longer (Hayward et al., 1997).

The relative gut length (RGL) of Nile tilapia was significantly higher in the 3-day fasting and 2-day fasting groups compared to those of the control and the one-day fasting groups, with significant differences among means $(\mathrm{P}<0.05)$.

One of the most widely recognized anatomical features of vertebrates is that herbivores exhibit longer digestive tracts than do carnivores, and this pattern appears to be consistent among mammals (Korn, 1992, Ellis, et al. 1994, Stevens and Hume, 1995), birds (Ricklefs, 1996, Battley and Piersma 2005), reptiles and amphibians (Stevens and Hume, 1995) and fishes (Kapoor, et al. 1975, Horn, 1989, Kramer and Bryant, 1995b).

Differences in body mass can also produce misleading results in comparisons of gut length because fishes that grow at faster rates tend to be heavier and exhibit longer guts than those grow at slower rates (Kramer and Bryant, 1995a). So, it is possible that changes in gut capacity may be a factor in this adaptation to recurring periods of deprivation and food abundance.

Although total feed intakes were significantly lower in all feed deprivation groups (45.4-59.0 g diet/fish) compared to the control group (72.7 g diet/fish) during the experiment FCR were similar among the fasting groups (1.47-1.54:1) and the control group (1.56:1). Fish during fasting period (21 days in each of the three cycles) consumed energy for routine metabolism needed for survival. Energy required for fish survival during the fasting period (21 days) was obtained from dietary energy consumed during previous re-feeding periods. This should have negatively affected FCR if this energy were to be deduced from the FI during the experiment.

All fasting treatments had similar FCR compared to the continuous feeding (control) group ( $p>0.05)$ which indicate that FCR in the feed deprivation groups was compensated during re-feeding by a decrease in metabolic costs or an improvement in feed utilization according to Uribinati et al. (2014).

It is concluded that intermediate periods of fasting ( 1 to 3 day fasting periods) followed by re-feeding ( 3 to 9 day refeeding periods) improved feed utilization in terms of FCR and resulted in similar FCR compared to the continuous feeding control group. Short periods of fasting up to 3 days did not negatively affect FCR. Similarly, survival of Nile tilapia was not 
affected by fasting up to 3 days ( 21 days during the experiment). Survival rates averaged 88.597.9\% in the feed deprivation groups, being similar to that of the control group (97.9\%), without significant differences among treatments.

FCR is important when feeding fish on a commercial scale as it allows farmers to balance growth with the economic costs of feed. Improving FE is also thought to reduce waste feed entering the environment. Tian and Qin (2004) observed no significant differences in FE in tropical fish barramundi (Lates calcarifer) and concluded that compensatory growth in this species was mainly attributed to hyperphagia during the period of satiation feeding. It has been postulated that improved feed conversion efficiency and/or digestive efficiency could contribute to the compensatory growth response (Qian et al., 2000, Eroldog et al., 2008).

Although Nile tilapia were exposed to intermittent fasting periods up to 3 days per one cycle, FCR and SR were not affected by several days of feed deprivation. The results of the current experiment are useful in fish farming since fish farmers are forced not to feed fish for several days in the case of excessive algal blooms or in the case of oxygen deterioration in fish ponds. Similarly, in practical situations fish should be deprived from feeding in the case of high ammonia concentrations in fish ponds to avoid the risk of ammonia toxicity. The current experiment indicated that in real situations, Nile tilapia will not be affected in terms of FCR or survival in the case of intermittent food deprivation when oxygen deterioration or ammonia toxicity occurs in the ponds. However, growth rates of Nile tilapia may be affected, and consequently production cycle should be extended in duration to allow fish experiencing longer term of starvation to compensate growth.

Moreover, intermittent fasting for up to 3 days per one cycle did not negatively affect FCR or SR. Consequently, it is safe to stop feeding fish for several days during water quality deterioration in earthen ponds. The results of the current experiment indicated that Nile tilapia will not be affected by short periods of intermittent fasting up to 3 days each.

Nikki et al. (2004) reported that in rainbow trout, hyperphagia was a response to food restriction whereas total deprivation generated an increase in growth efficiency during refeeding. The main effect of the intensity of the growth depression on the subsequent hyperphagia is on the duration of the hyperphagic phase, rather than a higher maximum rate of consumption (Russell and Wootton, 1992, Ali and Wootton, 2001, Xie et al., 2001, Zhu et al., 2001).

\subsection{Effect of fasting and re-feeding on the chemical composition.}

The summary of the results of the effect of fasting and re-feeding on the body composition of Oreochromis niloticus (Nile tilapia) is given in Table (5).

There were no significant differences $(\mathrm{P}>0.05)$ observed among the treatments in terms of whole body moisture content, protein content, lipid content, ash content and the gross energy content of body composition.

Xiao et al. (2013) reported that the ADCs of crude lipid were in general higher (values were above $98 \%$ ) and show no significant difference among the fish in different feeding regimes. Weatherley and Gill (1987) reported that the whole body and muscle composition were significantly affected by the periods of feed deprivation. Possible reason for explaining the response is that fish undergoing a period of starvation need to satisfy the energy requirements by utilizing lipid stores, with protein being used when lipid stores are depleted. The dorsal muscle and lipid contents were negatively correlated with feed-deprivation levels, while moisture tended to increase with increasing feed-deprivation days (Xiao et al., 2013).

\subsection{Water quality parameters}

The summary of the results of the effect of fasting and re-feeding on the water quality of tank of Nile tilapia is given in Table (6).

Nitrite concentration ranged 0.016 to 0.083 mg NO2-N among treatments, with no significant differences among means $(P>0.05)$. The concentration of nitrite remained within optimal level recommended for Nile tilapia culture according to Boyd and Green (1998).

Mean value of total ammonia nitrogen (TAN) was within the acceptable range considered suitable for Nile tilapia culture $(0.011$ to 0.062 mg TAN/L), with no significant differences among treatments $(\mathrm{P}>0.05)$. TAN and nitrite concentrations remained below 0.062 and 0.083 $\mathrm{mg}$, respectively during the experiment although fish were fed near satiation due to the daily renewal of water and the complete water renewal in experimental tanks every 4 days. 
Table (5) : Chemical composition of Nile tilapia reared under different fasting and re-feeding cycles

\begin{tabular}{|l|l|l|l|l|}
\hline Parameters & \multicolumn{1}{|c|}{ Control } & 3 day fasting & 2 day fasting & 1 day fasting \\
\hline Moisture & $63.66 \pm 0.98^{\mathrm{a}^{\mathrm{a}}}$ & $63.37 \pm 1.51^{\mathrm{a}}$ & $63.3 \pm 0.46^{\mathrm{a}}$ & $62.19 \pm 0.89^{\mathrm{a}}$ \\
\hline Protien & $58.5 \pm 0.52^{\mathrm{a}}$ & $55.96 \pm 1.2^{\mathrm{a}}$ & $58.72 \pm 1.32^{\mathrm{a}}$ & $57.6 \pm 0.92^{\mathrm{a}}$ \\
\hline Lipids & $23.23 \pm 1.32^{\mathrm{a}}$ & $25.1 \pm 1.32^{\mathrm{a}}$ & $23.5 \pm 0.82^{\mathrm{a}}$ & $27.57 \pm 1.28^{\mathrm{a}}$ \\
\hline Ash & $17.73 \pm 1.57^{\mathrm{a}}$ & $16.97 \pm 2.4^{\mathrm{a}}$ & $15.63 \pm 0.88^{\mathrm{a}}$ & $17.43 \pm 2.02^{\mathrm{a}}$ \\
\hline Gross energy & $550.08 \pm 14.59^{\mathrm{a}}$ & $553.09 \pm 18.88^{\mathrm{a}}$ & $553.82 \pm 8.08^{\mathrm{a}}$ & $585.9 \pm 7.27^{\mathrm{a}}$ \\
\hline
\end{tabular}

*Means in the same row with different superscripts are significantly different $(P<0.05)$

Table (6): Water quality parameters in rearing tanks under different fasting and re-feeding cycles

\begin{tabular}{|c|c|c|c|c|}
\hline Parameters & Control & 3 day fasting & 2 day fasting & 1 day fasting \\
\hline PH fasting day & $8.99 \pm 0.054^{\mathrm{a}^{*}}$ & $8.81 \pm 0.11^{\mathrm{a}}$ & $8.7 \pm 0.057^{\mathrm{a}}$ & $8.85 \pm 0.15^{\mathrm{a}}$ \\
\hline PH $1^{\text {st }}$ refed & $8.73 \pm 0.088^{\mathrm{a}}$ & $8.68 \pm 0.033^{\mathrm{a}}$ & $8.6 \pm 0.057^{\mathrm{a}}$ & $8.77 \pm 0.13^{\mathrm{a}}$ \\
\hline PH $2^{\text {nd }}$ refed & $8.87 \pm 0.03^{\mathrm{a}}$ & $8.83 \pm 0.03^{\mathrm{a}}$ & $8.46 \pm 0.03^{b}$ & $8.83 \pm 0.12^{\mathrm{a}}$ \\
\hline Nitrite fasting day & $0.11 \pm 0.032^{\mathrm{a}}$ & $0.14 \pm 0.031^{\mathrm{a}}$ & $0.08 \pm 0.026^{\mathrm{a}}$ & $0.083 \pm 0.033^{\mathrm{a}}$ \\
\hline Nitrite $1^{\text {st }}$ refed & $0.058 \pm 0.03^{\mathrm{a}}$ & $0.02 \pm 0.008^{\mathrm{a}}$ & $0.02 \pm 0.009^{\mathrm{a}}$ & $0.03 \pm 0.006^{\mathrm{a}}$ \\
\hline Nitrite $2^{\text {nd }}$ refed & $0.016 \pm 0.006^{\mathrm{a}}$ & $0.03 \pm 0.005^{\mathrm{a}}$ & $0.016 \pm 0.003^{\mathrm{a}}$ & $0.06 \pm 0.053^{\mathrm{a}}$ \\
\hline Nitrate fasting day & $2.5 \pm 0.15^{\mathrm{a}}$ & $2.26 \pm 0.14^{\mathrm{a}}$ & $2.56 \pm 0.38^{\mathrm{a}}$ & $2.93 \pm 0.40^{\mathrm{a}}$ \\
\hline Nitrate $1^{\text {st }}$ refed & $1.96 \pm 0.52^{\mathrm{a}}$ & $1.83 \pm 0.20^{\mathrm{a}}$ & $2.4 \pm 0.49^{\mathrm{a}}$ & $1.59 \pm 0.10^{\mathrm{a}}$ \\
\hline Nitrate $2^{\text {nd }}$ refed & $2.4 \pm 0.41^{\mathrm{a}}$ & $1.32 \pm 0.39^{\mathrm{a}}$ & $2.96 \pm 0.67^{\mathrm{a}}$ & $2.63 \pm 0.40^{\mathrm{a}}$ \\
\hline Ammonia fasting day & $0.016 \pm 0.003^{\mathrm{a}}$ & $0.062 \pm 0.04^{\mathrm{a}}$ & $0.023 \pm 0.003^{\mathrm{a}}$ & $0.017 \pm 0.004^{\mathrm{a}}$ \\
\hline Ammonia $1^{\text {st }}$ refed & $0.015 \pm 0.003^{\mathrm{a}}$ & $0.0157 \pm 0.003^{\mathrm{a}}$ & $0.013 \pm 0.003^{\mathrm{a}}$ & $0.011 \pm 0.002^{\mathrm{a}}$ \\
\hline Ammonia $2^{\text {nd }}$ refed & $0.019 \pm 0.001^{\mathrm{a}}$ & $0.025 \pm 0.004^{\mathrm{a}}$ & $0.015 \pm 0.003^{\mathrm{a}}$ & $0.021 \pm 0.002^{\mathrm{a}}$ \\
\hline
\end{tabular}

*Means in the same row with different superscripts are significantly different $(\mathbf{P}<0.05)$

Aquatic animals cannot separate their living space from their area of excretion. This causes deterioration in water quality inside the production system, leading to poor growth and an increase in the incidence of disease (Losordo et al., 1999). A proper feed ration and feeding method for each species should be adopted because feed waste constitutes a large part of waste production (Amirkolaie, 2011). As feed is the major source of waste in aquaculture, the management of aquaculture waste should be approached through diet formulation or feeding strategies. Ammonium is a by-product of protein catabolism. It has long been recognized that feeding excess protein will lead to catabolism of the amino acids associated with the excretion of ammonium and a loss of energy (Lloyd et al., 1978).

In the present study, the feeding level was stopped when fish were near satiation as recommended by Cho and Bureau (1997). Using this strategy led us to reduce feed costs and improve the water quality parameters, which constitute a major production cost in fish culture.

In addition to the protein content of feed, a balance between the digestible protein and digestible energy of the diets can result in an increase in $\mathrm{N}$ retention efficiency and a decrease in the ammonium-N/L among treatments .The overall mean values were approximately similar among treatments $(\mathrm{P}>0.05)$ due to the daily renewal of water in culture tanks and the complete renewal every 4 days. The nitrate concentrations ranged 1.32 to $2.96 \mathrm{mg} \mathrm{NO}$. Nitrate concentrations up to $220 \mathrm{mg} \mathrm{NO} 3-\mathrm{N}$ did not negatively affect survival and growth of aquatic animals (Kuhn et al., 2010). The high concentrations of nitrate in spite renewal could be due to the adhesion of nitrifying bacteria to tank wall which enhanced nitrate concentrations.

The $\mathrm{pH}$ levels ranged 8.46 to 8.99 with similar values among the food deprivation treatments and that of the control. Although nonsignificant, the slight variations in $\mathrm{pH}$ values among treatments may be due to the slight photosynthetic activities of algae in water of culture tanks.

In intensive aquaculture systems, $20-40 \%$ of the dietary dry matter is incorporated into the fish body and the remaining part is excreted (Verdegem et al., 1999). The amount of faecal waste ranges between 0.2 and $0.5 \mathrm{~kg}$ dry matter per $\mathrm{kg}$ feed (Chen et al., 1997). 


\section{Conclusion}

It is concluded that intermediate periods of fasting (1 to 3 day fasting periods) followed by re-feeding ( 3 to 9 day refeeding periods) improved feed utilization and resulted in similar feed conversion ratio compared to the continuous feeding control group. Short periods of fasting up to 3 days did not negatively affect feed conversion ratio. Similarly, survival of Nile tilapia was not affected by fasting for up to 3 days (21 days during the experiment). The results of the current experiment are useful in fish farming since fish farmers are forced not to feed fish for several days in the case of excessive algal blooms or in the case of oxygen deterioration in fish ponds. Similarly, in practical situations fish should be deprived from feeding in the case of high ammonia concentrations in fish ponds to avoid the risk of ammonia toxicity.

\section{REFERENCES}

Ali M. and Wootton R.J. (2001). Capacity for growth compensation in juvenile threespined sticklebacks experiencing cycles of food deprivation. J. Fish Biol. 58: 15311544.

Ali M., Nicieza A. and Wootton, R.J. (2003). Compensatory growth in fishes: a response to growth depression. Fish Fish., 4: 147190.

Amirkolaie A. K. (2011). Reduction in the environmental impact of waste discharged by fish farms through feed and feeding. Rev. in Aquacul., 3(1): 19-26.

Battley P.F. and Piersma T. (2005). Adaptive interplay between feeding and ecology and features of the digestive tract in birds. In: Starck JM, Wang T (eds) Physiological and Ecological Adaptations to Feeding in Vertebrates. Science Publishers Inc., Enfield, volume 201-228

Boujard T., Burel C., Medale F., Haylor G. and Moisan A. (2000). Effect of past nutritional history and fasting on feed intake and growth in rainbow trout (Oncorhynchus mykiss).Aquat.Living Resour.,13: 129- 137.

Boyd C. E. and Green B. (1998). Dry matter, ash, and elemental composition of pondcultured tilapia (Oreochromis aureus and O. niloticus).J.World Aquat. Soc.,29:125128

Chen S., Coffin D.E. and Malone R.F. (1997). Sludge production and management for recirculating aquaculture system. J. World Aquacult. Soc., 28: 303-315.

Cho C.Y. and Bureau D.P. (1997). Reduction of waste output from salmonid aquaculture through feeds and feeding. The Progressive Fish-Culturist, 59: 155-160.

Dobson S.H. and Holmes R.M. (1984). Compensatory growth in the rainbow trout, Salmo gairdneri Richardson. J. Fish Biol., 25: 649-656.

Ellis B.A., Mills J.N., Kennedy J.T., Maiztegui, J.I. and Childs J.E. (1994). The relationship among diet, alimentary tract morphology, and life history for five species of rodents from the central Argentine pampa. Acta Theriol., 39:345-355

Eroldog O.T., Tas`bozan O. and Tabakog`lu, S. (2008). Effects of restricted feeding regimes on growth and feed utilization of juvenile gilthead sea bream, (Sparus aurata) J. World Aquacul. Soc., Vol. 39 (2) April, 2008.

Gaylord T.G. and Gatlin III, D.M. (2001). Dietary protein and energymodifications tomaximize compensatory growth of channel catfish (Ictalurus punctatus). Aquacul., 194: 337-348.

Gurney W.S.C., Jones W., Veitch A.R. and Nisbet, R.M. (2003). Resource allocation, hyperphagia, and compensatory growth in juveniles. Ecol., 34 (10): 2777-2787.

Hayward R.S., Noltie, D.B. and Wang, N. (1997). Use of compensatory growth to double hybrid sunfish growth rates. Transac. Am Fish Soc., 126: 316-322.

Horn M.H. (1989). Biology of marine herbivorous fishes. Oceanogr. Mar. Biol .Ann. Rev. 27:167-272

Jobling M., Meløy O.H., Dos Santos J. and Christiansen B. (1994). The compensatory growth response of the Atlantic cod: effects of nutritional history.Aquacul Int'1., 2(2): 75-90.

Jobling M. (1993). Bioenergetics: feed intake and energy partitioning. In: Fish Ecophysiology (eds J.C. Rankin and F.B. Jensen), Chapman \& Hall, London, Vol.1,44. J. of the World Aquacult. Soc., 39: 267-274.

Jobling, M. (2010). Are compensatory growth and catch-up growth two sides of the same coin? Aquacul Int'1. 18:501-510.

Känkänen M. and Pirhonen J. (2009). The effect of intermittent feeding on feed intake and 
compensatory growth of whitefish (Coregonus lavaretus) L. Aquacult., 288:92-97

Kapoor B.G., Smit H. and Verighina I.A. (1975). The alimentary canal and digestion in teleosts. Adv. Mar. Biol. 13:109-239

Kindschi G.A. (1988). Effect of intermittent feeding on growth of rainbow trout, Salmo gairdneri Richardson. Aquacult. Fish. Manage., 19: 213-215.

Korn H. (1992). Intestine lengths of Southern African savanna rodents and insectivores: intra- and interspecific comparisons. J. Zool. 228:455-460

Kramer D.L. and Bryant M.J. (1995a). Intestine length in the fishes of a tropical stream: 1. Ontogenetic allometry. Environ. Biol. Fish. 42:115-127.

Kramer D. L. and Bryant M. J. (1995b). Intestine length in the fishes of a tropical stream: 2. Relationships to diet-the long and short of a convoluted issue. Environ. Biol. Fishs, 42(2): 129-141.

Kuhn D.D., Lawrence A.L., Boardman G.D., Patnaik S., Marsh L. and Flick, G. J. (2010). Evaluation of two types of bioflocs derived from biological treatment of fish effluent as feed ingredients for Pacific white shrimp, Litopenaeus vannamei. Aquacul,303 (1): 28-33.

Lloyd L.E., McDonald B.E. and Crampton E.W. (1978). Fundamentals of Nutrition, 2nd edn. WH. Freeman, San Francisco, California, USA.

Losordo T.M., Masser M.P. and Rakocy J.E. (1999). Recirculating aquaculture tank production systems: a review of component options. SRAC (Publication no. 453).

Miglavs I. and Jobling M. (1989). Effects of feeding regime on food consumption, growth rates and tissue nucleic acids in juvenile Arctic charr, Salvelinus alpinus, with particular espect to compensatory growth. J. Fish Biol. 34:947-957.

Nebo C., Portella M.C., Carani F.R., Almeida F.L.A., Padovani C.R., Carvalho R.F. and Dal-Pai- Silva M. (2013). Short periods of fasting followed by refeeding change the expression of muscle growth-related genes in juvenile Nile tilapia (Oreochromis niloticus). Comp.Biochem. Physiol., B 164: 268-274.

Nikki J., Pirhonen J., Jobling M. and Karjalainen J. (2004). Compensatory growth in juvenile rainbow trout, Oncorhynchus mykiss
(Walbaum), held individually. Aquacul.

235: 285-296.

O'Connor K.I., Taylor A.C. and Metcalf M.B. (2000). The stability of standard metabolic rate during a period of food deprivation in juvenile Atlantic salmon. J. Fish Biol. 57: 41-51.

Paul A.J., Paul J.M. and Smith R.L. (1995). Compensatory growth in Alaska yellowfin sole, Pleuronectes asper, following food deprivation. J. Fish Biol., 46: 442-448.

Pitts G.C. (1986). Cellular aspects of growth and catch-up growth in the rat: a reevaluation. Growth 50: 419-436.

Qian X., Cui Y., Xiong B. and Yang Y. (2000). Compensatory growth, feed utilization and activity in gibel carp, following feed deprivation. J. Fish. Biol., 56: 228-232.

Quinton J.C. and Blake R.W. (1990). The effect of feed cycling and ration level on the compensatory growth response in rainbow trout Oncorhynchus mykiss. J. Fish Biol., 37: 33-41.

Ricklefs R.E. (1996). Morphometry of digestive tracts of some passerine birds. Condor, 98:279-292

Russell N.R. and Wootton R.J. (1992). Appetite and growth compensation in the European minnow, Phoxinus phoxinus (Cyprinidae) following short periods of food restriction. Environ. Biol., Fishes, 34: 277- 285.

Silverstein J.T. (2006). Relationships among feed intake, feed efficiency, and growth in juvenile rainbow trout. North Am. J. Aquacul., 68: 168-175.

Skalski G.T., Picha M.E., Gilliam J.F. and Borski R.J. (2005). Variable intake, compensatory growth, and increased growth efficiency in fish: models and mechanisms. Ecol., 86:1452-1462.

Stevens C.E. and Hume I.D. (1995). Comparative Physiology of the Vertebrate Digestive System. Press Syndicate, University of Cambridge, Melbourne, Australia.

Suloma A. and Ogata H. Y. (2006). Future of rice-fish culture, desert aquaculture and feed development in Africa: the case of Egypt as the leading country in Africa. Japan Agri. Res. Quart., JARQ, 40 (4):351360.

Suloma A., Ogata H. Y., Garibay E.S., Chavez D.R. and El-haroun E.R. (2008). Fatty acid composition of Nile tilapia Oreochromis niloticus muscles: a comparative study with 
commercially important tropical freshwater fish in Philippines. In 8th International symposium on tilapia aquaculture. Cairo, Egypt (Vol. pp921-932).

Suloma A. and Ogata H.Y. (2012). Lipid and fatty acid composition of commercially important tropical freshwater fish gonads: guidelines for specific broodstock diet. Turkish J. Fisheries and Aquatic Sci, 12(4).

Suresh V. (2003). Tilapias. In: Lucas, J.S. and Southgate, P.C., (Eds.) Aquaculture: Farming of Aquatic Animals and Plants, Volume. 321-345.

Tacon A.G.J. (1987). The nutrition and feeding of farmed fish and shrimp. A Training Manual 2. Nutrient Sources and Composition. Brasilia, Brazil: FAO Field Document No. 128.

Tian X. and Qin J. G. (2004). Effects of previous ration restriction on compensatory growth in barramundi (Lates calcarifer). Aquacul., 235(1): 273-283.

Urbinati E.C., Sarmiento S.J. and Takahashi L.S. (2014). Short-term cycles of feed deprivation and refeeding promote full compensatory growth in the Amazon fish matrinxã (Brycon amazonicus). Aquacul 433: 430-433.

Verdegem M.C.J., Eding E.H., van Rooij J.M. and Verreth J.V.J. (1999). Comparison of effluents from pond and recirculating production systems using formulated diets. World Aquacul., 30: 28-36.

Wang Y., Cui Y., Yang Y. and Cai F. (2000). Compensatory growth in hybrid tilapia, Oreochromis mossambicus x O. niloticus, reared in sea water. Aquacul 189: 101-108.

Weatherley A. H. and Gill H.S. (1981). Recovery growth following periods of restricted rations and starvation in rainbow trout, Salmo gairdneri Richardson. J. Fish Biol., 18: 195-208.

Weatherley A.H. and Gill H.S. (1987). The Biology of Fish Growth Academic Press, London., Volume 443.

Williams S. (1984). Official Methods of Analysis of the AOAC (Volume 1).

Wilson P.N. and Osbourne D.F. (1960). Compensatory growth after undernutrition in mammals and birds. Biol. Rev., 37: 324363.

Wootton R.J. (1998). The ecology of teleost fishes. $2^{\text {nd }}$ edn. Fish \& Fisheries Series, no. 24. Dordrecht: Kluwer.

Xiao J. X., Zhou F., Yin N., Zhou J., Gao S., $\mathrm{Li} \quad \mathrm{H}$., and $\mathrm{Xu}$ J. (2013). Compensatory growth of juvenile black sea bream, Acanthopagrus schlegelii with cyclical feed deprivation and refeeding. Aquacul. Res., 44(7): 1045-1057

Xie S., Zhu X., Cui Y., Wootton R.J., Lei W. and Yang Y. (2001). Compensatory growth in the gibel carp following feed deprivation: temporal patterns in growth, nutrient deposition, feed intake and body composition. J. Fish. Biol., 58: 999- 1009.

Zhu X., Cui Y., Ali M. and Wootton R.J. (2001). Comparison of compensatory growth responses of juvenile threespined stickleback and minnow following similar food deprivation protocols. J. Fish Biol., 58: $1149-1165$.

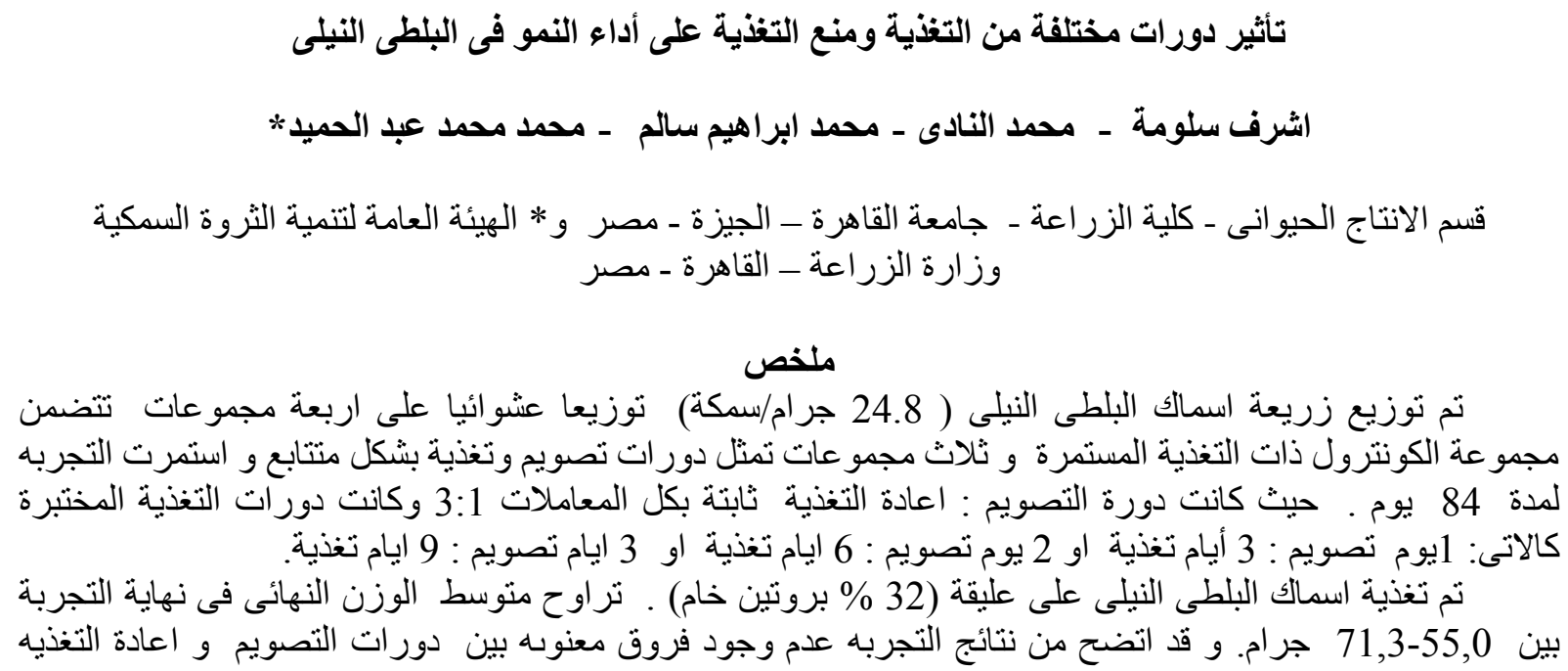




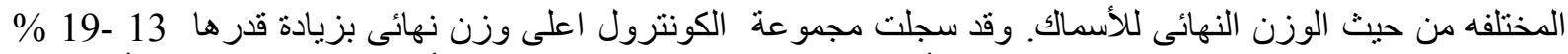

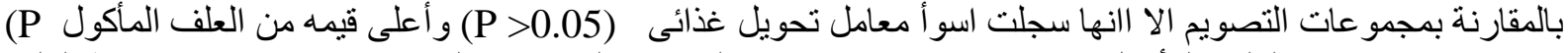

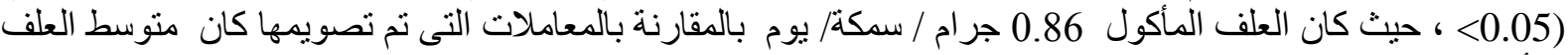

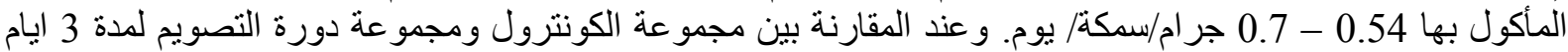

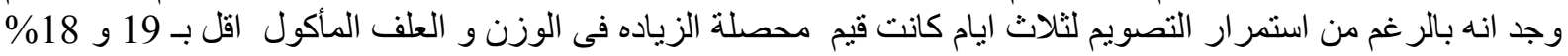

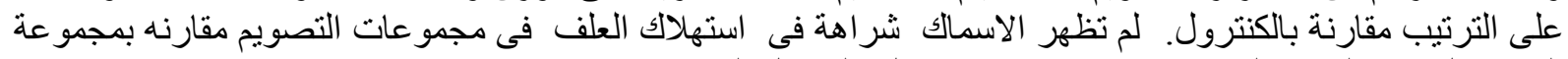

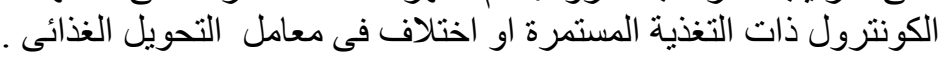

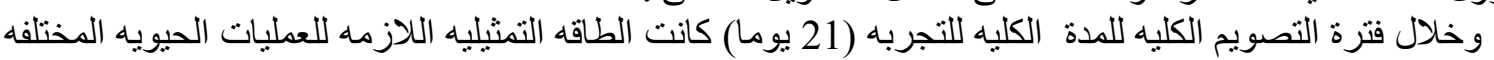

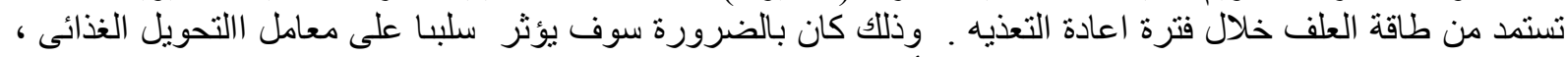

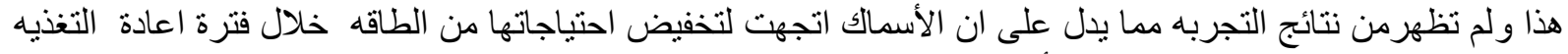

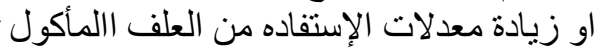
المجلة العلمية لكلية الزراعة - جامعة القاهرة - المجلد (66)العدد الثالث (يوليو 2015): 212-222 ـ 